\title{
Role of platelet-derived growth factor in development of in vitro matured and in vitro fertilized bovine embryos
}

\author{
J. K. Thibodeaux, R. P. Del Vecchio* and W. Hansel $\dagger$ \\ Departments of Animal Science and Veterinary Science, LAES, LSU Agricultural Center, \\ Louisiana State University, Baton Rouge, LA 70803, USA
}

\begin{abstract}
This experiment was designed to determine whether the stimulatory effects of bovine oviductal epithelial cells (BOEC) on development of early bovine embryos are due to platelet-derived growth factor (PDGF). Four hundred and twenty five 8-cell bovine embryos derived from in vitro maturation and in vitro fertilization procedures were equally and randomly allotted to one of the following culture treatment groups: control medium alone (Menezo's B2 medium; MB2), MB2 with $1 \mathrm{ng}$ PDGF ml ${ }^{-1}$ (PDGF), $1 \mathrm{ng}$ PDGF ml ${ }^{-1}$ and $10 \mu \mathrm{g}$ anti-PDGF antibody $\mathrm{ml}^{-1}$ (PDGF $+\mathrm{Ab}$ ), BOEC or BOEC and $10 \mu \mathrm{g}$ anti-PDGF antibody $\mathrm{ml}^{-1}$ (BOEC + Ab). All embryos were cultured in $100 \mu \mathrm{l}$ of serum-free MB2 medium supplemented with $2 \mathrm{mg}$ fatty-acid-free bovine serum albumin $\mathrm{ml}^{-1}$. Embryos for all treatment groups were incubated at $39^{\circ} \mathrm{C}$ and $5 \% \mathrm{CO}_{2}$ in humidified air in groups of five embryos per well in 96-well culture plates until 7 days after in vitro insemination. A higher proportion of embryos developed to $>8$-cell and to the morula stage following culture with PDGF, BOEC or BOEC + Ab than with MB2 alone. Incubation of PDGF and BOEC-treated embryos with anti-PDGF reduced development to the morula and blastocyst stages. However, anti-PDGF did not completely inhibit blastocyst development when added to BOEC. In addition, embryos incubated with BOEC and anti-PDGF contained a reduced number of inner cell mass cells compared with embryos incubated with BOEC alone. These results indicate that PDGF provides a developmental stimulus similar to BOEC for bovine embryos at the fourth cell cycle. The addition of PDGF antibodies appears to reduce early embryo development by inhibiting PDGF action. However, BOEC may also produce factors other than PDGF that are beneficial to early bovine embryo development during in vitro culture.
\end{abstract}

\section{Introduction}

The development of embryo co-culture systems using various types of 'helper cell' has provided a more efficient means of maintaining embryos in vitro for extended periods with minimal reduction in viability (see review by Rexroad, 1989). Culture systems, such as uterine fibroblasts (Voelkel et al., 1985; Wiemer et al., 1988), and epithelial cells (Goodeaux et al., 1990), oviduct cells (Gandolfi and Moor, 1987; Rexroad and Powell, 1988; Ellington et al., 1989; Eyestone and First, 1989; McCaffery et al, 1991), trophoblastic vesicles (Camous et al., 1984; Heyman et al., 1987; Pool et al., 1988), granulosa cells (Fukuda et al., 1990; Zhang et al., 1992), chick embryo amnion (Blakewood et al., 1989; Blakewood et al., 1990) and conditioned medium (Eyestone and First, 1989; Eyestone et al., 1991; Pinyopummintr and Bavister, 1991), have allowed researchers to study embryonic development in farm animal species during prolonged in vitro culture. Although the beneficial effects of co-culture systems have been demonstrated by many different laboratories in recent years, the biochemical components and

*Present address: Agriculture Canada Research Station, Brandon, Manitoba R7A 5 Y3, Canada.

†Correspondence and reprint requests.

Received 2 April 1992 interactions between the developing embryo and cellular monolayers are not well understood.

Embryonic development consists of a series of events including cell proliferation and differentiation in which several growth factors appear to play key regulatory roles. It is possible that the embryotrophic effects of co-culture systems are mediated via the secretion of one or more growth factors. This suggestion is further strengthened by a recent report of the detection of platelet-derived growth factor (PDGF) in bovine oviductal secretions (Gandolfi et al., 1991). In addition, one research group (Larson et al., 1992) reported that the addition of $1 \mathrm{ng}$ PDGF $\mathrm{ml}^{-1}$ to the culture medium induced bovine embryos to develop beyond the 8- to 16-cell 'block' stage. Larson et al. (1992) noted that PDGF activated specific protooncogenes and reduced the duration of the fourth cell cycle. Other growth factors, such as fibroblast growth factor (bFGF) and transforming growth factor $\alpha$ (TGF- $\alpha$ ), appear to play more significant roles at the fifth cell cycle (Larson et al., 1992) but TGF- $\beta$ may also act synergistically with epidermal growth factor (EGF) to increase the incidence of hatched blastocysts in bovine embryos matured and fertilized in vitro (Keefer, 1992).

The present experiment was designed to study the role of PDGF in early bovine embryo development and to test the hypothesis that all, or part, of the beneficial effects of co-culture 
of early bovine embryos with bovine oviductal epithelial cells (BOEC) is due to PDGF.

\section{Materials and Methods}

\section{Experimental embryos}

Bovine embryos were produced using modifications to procedures described by Thibodeaux et al. (1992) for in vitro maturation (IVM) and in vitro fertilization (IVF) of follicular oocytes. Ovaries used for harvesting cumulus-intact oocytes were obtained from a local abattoir and from an abattoir in South Carolina. Ovaries were packaged in thermal containers in phosphate-buffered saline (PBS; Gibco Laboratories, Grand Island, $N Y$ ) and reached the laboratory $4-8 \mathrm{~h}$ after collection. Upon reaching the laboratory, ovaries were washed several times with fresh PBS containing antibiotics (100 units penicillin and $100 \mu \mathrm{g}$ streptomycin $\mathrm{ml}^{-1}$; Gibco). Oocytes were then aspirated from $2-6 \mathrm{~mm}$ follicles using a 20 gauge needle with a $10 \mathrm{ml}$ syringe. Initially, cumulus-intact oocytes were matured for $22-24 \mathrm{~h}$ at $39^{\circ} \mathrm{C}$ and $5 \% \mathrm{CO}$ in humidified air in 4-well culture plates (Nunclon, Naperville, IL) containing $500 \mu \mathrm{l}$ of IVM medium overlaid with mineral oil (E. R. Squibb and Sons, Inc., Princeton, NJ). The IVM medium consisted of Tissue Culture Medium-199 (TCM-199; Gibco) supplemented with $10 \%$ heat-treated fetal bovine serum (FBS; Hyclone Laboratories, Logan, UT), antibiotics and hormones (0.01 iu purified bovine $\mathrm{FSH}$ and $\mathrm{LH} \mathrm{ml}^{-1}$; NOBL Laboratories, Sioux Center, IA).

After IVM, oocytes were washed twice with BO medium (Brackett and Oliphant, 1975) containing $20 \mathrm{mg} \mathrm{BSA} \mathrm{ml}^{-1}$ (Sigma Chemical Co., St Louis, MO) and transferred to $50 \mu \mathrm{l}$ drops of BO medium containing BSA overlaid with mineral oil. For IVF, two straws of frozen-thawed semen from the same Holstein bull were washed twice in $\mathrm{BO}$ medium supplemented with $10 \mathrm{mmol}$ caffeine sodium benzoate $\mathrm{l}^{-1}$ (Sigma) $(6 \mathrm{ml}$ per wash) and exposed to $0.1 \mu \mathrm{mol} \mathrm{Ca}{ }^{2+}$ ionophore $\mathrm{A} 23187$ $\mathrm{I}^{-1}$ (Sigma) for $1 \mathrm{~min}$. A $50 \mu \mathrm{l}$ portion of sperm cells containing $1.5 \times 10^{6}$ motile sperm cells $\mathrm{ml}^{-1}$ was added to oocytes (15-20 oocytes per droplet) after exposure to $\mathrm{Ca}^{2+}$ ionophore and incubated for an additional $5-6 \mathrm{~h}$ at $39^{\circ} \mathrm{C}$ and $5 \% \mathrm{CO}_{2}$ in humidified air. After the insemination interval, oocytes were washed twice in TCM-199 with $10 \%$ FBS and antibiotics, then incubated for an additional $56-60 \mathrm{~h}$ at $39^{\circ} \mathrm{C}$ and $5 \% \mathrm{CO}_{2}$ in humidified air before allocation to treatment groups.

\section{Isolation and culture of oviduct cells}

Bovine oviducts were obtained at a local abattoir from animals in the early luteal stage of the oestrous cycle and transported to the laboratory on ice in $\mathrm{Ca}^{2+}$ - and $\mathrm{Mg}^{2+}$-free PBS (Sigma) supplemented with 200 units penicillin, $200 \mu \mathrm{g}$ streptomycin and $0.25 \mu \mathrm{g}$ amphotericin $\mathrm{B} \mathrm{ml}^{-1}$. Oviductal cells from both oviducts were stripped with fine forceps from the isthmus distal to the infundibulum as described by Thibodeaux et al. (1992) and resuspended in TCM-199 with 10\% FBS and antibiotics. Oviductal cells were washed with fresh cell culture medium and portions of the cell suspension incubated in 96-well plates (100 $\mu$ l suspension per well) at $39^{\circ} \mathrm{C}$ and $5 \% \mathrm{CO}_{2}$ in humidified air. Oviductal cells were used for embryo culture experiments upon reaching confluency, usually within $96 \mathrm{~h}$ of initial cell seeding.

\section{Embryo culture}

Early 8-cell stage bovine embryos were harvested from the initial culture (TCM-199 with 10\% FBS and antibiotics) $56-60 \mathrm{~h}$ following IVF. The duration from insemination to harvesting embryos was based on the length of the first four cell cycles as previously reported (Barnes and Eyestone, 1990; Barnes and First, 1991). Larson (1991) indicated that the beneficial effects of PDGF on bovine embryo development occurred at the fourth cell cycle. Embryos were washed several times in serum-free Menezo's B2 medium (MB2; Menezo et al., 1984; API Biomerieux, France) then equally and randomly allotted to one of five culture treatment groups as follows: control medium alone (MB2), MB2 with $1 \mathrm{ng}$ PDGF $\mathrm{ml}^{-1}$ (PDGF), $1 \mathrm{ng}$ PDGF $\mathrm{ml}^{-1}$ and $10 \mu \mathrm{g}$ anti-PDGF antibody $\mathrm{ml}^{-1}$ (PDGF $+\mathrm{Ab}$ ), BOEC or $B O E C$ and $10 \mu \mathrm{g}$ anti-PDGF antibody $\mathrm{ml}^{-1}$ (BOEC $+\mathrm{Ab}$ ).

The anti-PDGF antibody used was a goat anti-human polyclonal IgG raised against both the $A$ and $B$ chains of PDGF (UBI; Upstate Biotechnology, Inc., Lake Placid, NY). Purification of the IgG fraction of goat serum was by DEAE ion-exchange chromatography. The antibody was used at a concentration of $10 \mu \mathrm{g} \mathrm{ml}^{-1}$ for embryo culture studies. This was based on the suppliers report that $25 \mu \mathrm{g}$ anti-PDGF $\mathrm{ml}^{-1}$ will neutralize $(100 \%) 10 \mathrm{ng}$ PDGF-AB ml $\mathrm{m}^{-1}$ or $10 \mathrm{ng}$ PDGF-BB ml $\mathrm{m}^{-1}$ and $100 \mu \mathrm{g}$ anti-PDGF $\mathrm{ml}^{-1}$ will neutralize (100\%) $10 \mathrm{ng}$ PDGF$\mathrm{AA} \mathrm{m} l^{-1}$ of human, primate, porcine, bovine and murine origin based on the tritiated thymidine incorporation assay using NIH$3 \mathrm{~T} 3$ cells. The antibody exhibited no crossreactivity $(<0.1 \%)$ with IGF-I, TGF- $\beta$, acidic FGF, basic FGF or EGF when Western blot analysis and a biological neutralization assay were used.

Embryos were incubated in 96-well culture plates in serumfree MB2 medium without antibiotics in $100 \mu \mathrm{l}$ of medium overlaid with mineral oil. All treatment groups were supplemented with $2 \mathrm{mg}$ fatty-acid-free BSA $\mathrm{ml}^{-1}$ to prevent rapid degradation of growth factors and their adherence to culture wells. Embryos in each treatment group ( $n=85$ embryos per treatment) were incubated at $39^{\circ} \mathrm{C}$ and $5 \% \mathrm{CO}_{2}$ in humidified air in groups of five embryos per well. Once embryos were assigned to treatment groups, the culture medium was not changed during the incubation interval and embryos remained undisturbed for the remainder of the culture period. The proportions of embryos developing beyond the 8-cell, or to the morula or blastocyst stages of development were determined 7 days following in vitro insemination.

\section{Embryo staining}

After the in vitro culture period, a random portion of embryos in each treatment group between $>8$-cell and morula stages was stained to evaluate the number of nuclei per embryo using a DNA-specific stain, Hoechst 33342 (Pursel et al., 1985). When blastocysts were formed during the treatment culture period, a double-dye technique for differential cell counts of inner cell mass and trophectoderm nuclei was performed as reported by Iwasaki et al. (1990). Initially, the 
Table 1. Proportion of bovine embryos developing to at least the morula or blastocyst stage on day 7 following in vitro insemination

\begin{tabular}{lcccc}
\hline Treatment & $\begin{array}{c}\text { Number of } \\
\text { embryos }\end{array}$ & $\begin{array}{c}>8 \text {-Cell } \\
(\%)^{*}\end{array}$ & $\begin{array}{c}\text { Morula } \\
(\%)^{*}\end{array}$ & $\begin{array}{c}\text { Blastocyst } \\
(\%)^{*}\end{array}$ \\
\hline MB2 & 85 & $29.3 \pm 6.1^{\mathrm{a}}$ & $14.0 \pm 4.1^{\mathrm{a}}$ & $0 \pm 0^{\mathrm{a}}$ \\
PDGF & 85 & $61.3 \pm 7.0^{\mathrm{bc}}$ & $39.1 \pm 5.8^{\mathrm{b}}$ & $3.3 \pm 2.9^{\mathrm{a}}$ \\
PDGF $+\mathrm{Ab}$ & 85 & $31.2 \pm 4.3^{\mathrm{a}}$ & $19.6 \pm 3.9^{\mathrm{ac}}$ & $0 \pm 0^{\mathrm{a}}$ \\
BOEC & 85 & $74.4 \pm 3.9^{\mathrm{b}}$ & $60.4 \pm 2.5^{\mathrm{d}}$ & $27.6 \pm 5.6^{\mathrm{b}}$ \\
BOEC $+\mathrm{Ab}$ & 85 & $46.8 \pm 5.8^{\mathrm{ac}}$ & $32.6 \pm 5.0^{\mathrm{bc}}$ & $16.7 \pm 3.8^{\mathrm{c}}$ \\
\hline
\end{tabular}

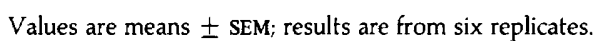

Values within columns with different superscripts are significantly different $(P<0.05)$.

MB2: Menezo's B2 medium; PDGF: platelet-derived growth factor; Ab: platelet-derived growth factor antibody; BOEC: bovine oviductal epithelial cells.

*Percentages are cumulative values for all embryos developing beyond the 8-cell stage and at least the morula or blastocyst stage following initiation of treatments.

zona pellucida was removed from blastocysts with acid Tyrode's solution and embryos were subsequently washed in TCM-199 with $10 \%$ FBS. Zona-free blastocysts were incubated with mouse anti-bovine antiserum (1:5 dilution) at $39^{\circ} \mathrm{C}(5 \%$ $\mathrm{CO}$, in humidified air) for $30 \mathrm{~min}$. After several washes in TCM199 with $10 \% \mathrm{FBS}$, blastocysts were incubated $\left(39^{\circ} \mathrm{C}\right.$ and $5 \%$ $\mathrm{CO}_{2}$ in humidified air) with guinea-pig complement serum (Sigma; 1:10 dilution), $10 \mu \mathrm{g}$ propidium iodide $\mathrm{ml}^{-1}$ (Sigma) and $10 \mu \mathrm{g}$ Hoechst $33258 \mathrm{ml}^{-1}$ (Sigma) for $30 \mathrm{~min}$. Embryos were subsequently washed in TCM-199 with 10\% FBS and mounted on a glass slide for evaluation.

\section{Statistical analysis}

For embryo culture data, a randomized complete block design was used with an experimental unit consisting of five embryos incubated within $100 \mu \mathrm{l}$ medium per well. One experimental block consisted of a group of oocytes matured, fertilized and the resulting 8-cell embryos were incubated together. The proportions of embryos in each experimental unit that developed to a specific stage divided by the total number of embryos in each unit were analysed using analysis of variance and Tukey's test to determine significance among treatment means (Steel and Torrie, 1980).

Results comparing the mean number of nuclei per embryo were evaluated using one-way analysis of variance and Tukey's test to separate treatment means. In addition, the total number of cells and the number of inner cell mass cells, and the proportion of inner cell mass to total cell number was evaluated using analysis of variance and means separated by Tukey's test.

\section{Results}

Co-culture with BOEC resulted in the highest proportion of embryos developing beyond the fourth cell cycle (>8-cell). However, these results were not different $(P>0.05)$ from those observed for PDGF-treated embryos (Table 1). A higher $(P<0.05)$ proportion of embryos developed to $>8$-cells

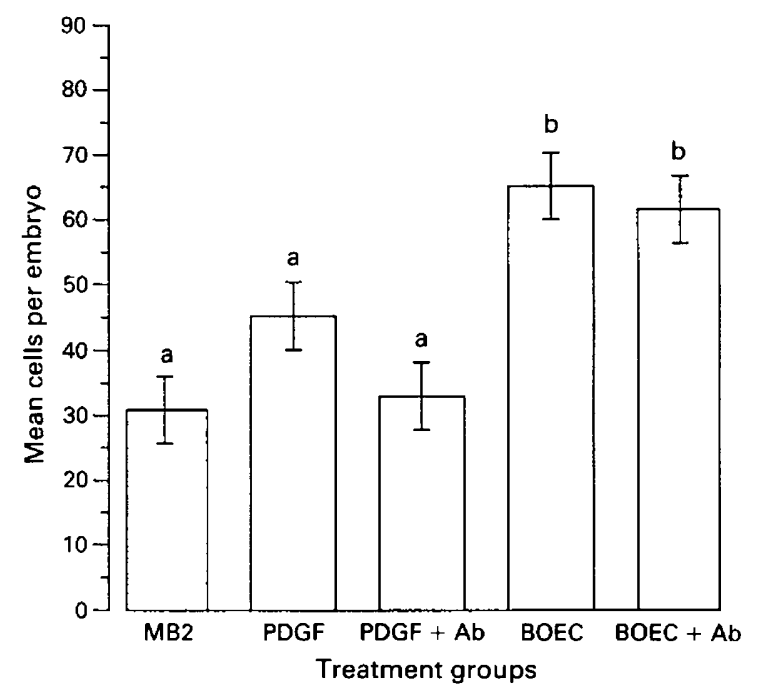

Fig. 1. The mean number ( \pm SEM) of cells per embryo evaluated 7 days after in vitro insemination. Only embryos developing between $>8$-cell and morula stages were stained and evaluated. Values with different letters above error bars indicate a significant difference $(P<0.05)$. MB2: Menezo's B2 medium; PDGF: platelet-derived growth factor; Ab: platelet-derived growth factor antibody; BOEC: bovine oviductal epithelial cells.

following incubation with PDGF or BOEC than in the MB2 or $\mathrm{PDGF}+\mathrm{Ab}$ treatment groups. However, there was no difference between the proportion of embryos developing to this stage after culture with BOEC + $\mathrm{Ab}$ or PDGF.

A similar developmental pattern was noted for those embryos that developed to at least the morula stage 7 days following in vitro insemination (Table 1). The proportion of embryos developing to the morula stage was higher $(P<0.05)$ following culture with PDGF, BOEC or BOEC $+\mathrm{Ab}$ than those in $\mathrm{MB} 2$ and PDGF $+\mathrm{Ab}$ culture groups. Incubation of PDGF- and BOEC-treated embryos with anti-PDGF inhibited development to the morula and blastocyst stages. Although incubation of embryos with BOEC and anti-PDGF reduced embryo development to the blastocyst stage, it did not completely inhibit blastocyst development. No embryos reached 

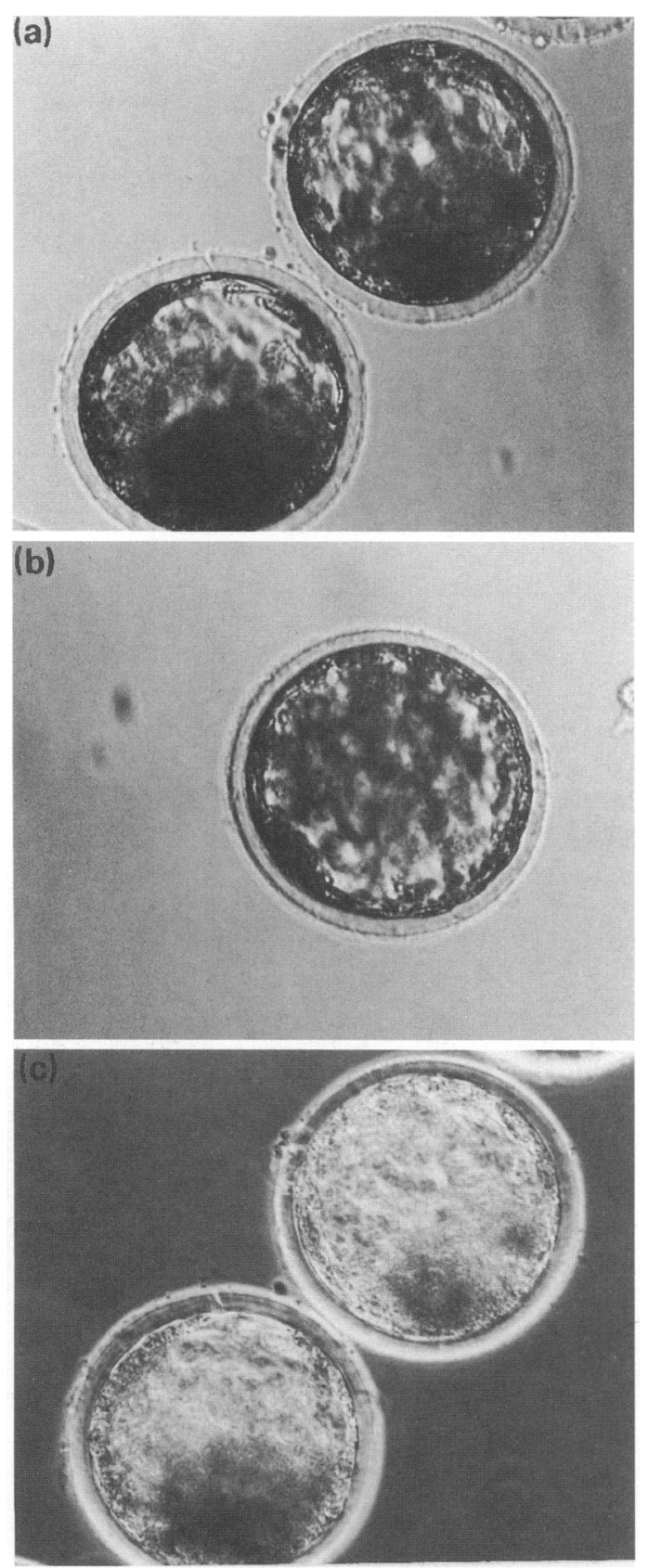

Fig. 2. Comparison of bovine embryos incubated with (a) bovine oviductal epithelial cells (BOEC) or (b) BOEC + platelet-derived growth factor antibodies (Ab). Note in (c) that the embryo on the bottom left has a distinct inner cell mass after co-culture with BOEC, whereas the embryo on the top right has a small or undefined inner cell mass after co-culture with BOEC $+\mathrm{Ab}(\times 200)$.

the blastocyst stage on day 7 following insemination with MB2 or PDGF $+\mathrm{Ab}$, which was lower $(P<0.05)$ than for embryos incubated in BOEC or $\mathrm{BOEC}+\mathrm{Ab}$ treatment groups. In addition, more $(P<0.05)$ blastocysts were formed following incubation with BOEC and BOEC + Ab compared with PDGFtreated embryos. However, incubation of embryos with $\mathrm{BOEC}$ resulted in a higher $(P<0.05)$ proportion reaching the blastocyst stage, than in all other treatment groups.
The mean number of nuclei per embryo was evaluated for those embryos between $>8$-cell and morulae stages of development (Fig. 1). Incubation of embryos with BOEC or $\mathrm{BOEC}+\mathrm{Ab}$ increased the number of nuclei per embryo $(P<0.05)$. The mean number of nuclei per embryo for BOEC (65.1) and BOEC + $\mathrm{Ab}(61.2)$ was higher $(P<0.05)$ than those for embryos incubated in MB2, PDGF or PDGF + Ab (30.8, 45.2 and 33.0, respectively). The number of nuclei per embryo was similar $(P>0.05)$ for embryos incubated in MB2, PDGF or $\mathrm{PDGF}+\mathrm{Ab}$.

Those embryos incubated in BOEC $+\mathrm{Ab}$ appeared to have a small inner cell mass, or the inner cell mass was not clearly distinguishable. In contrast, embryos incubated with BOEC alone had a distinct uniform inner cell mass (Fig. 2). The differential staining procedure indicated that the total number of cells per blastocyst was not significantly different $(P>0.05)$ between BOEC and BOEC + Ab treatment groups (Table 2). However, the number of inner cell mass cells was reduced $(P<0.05)$ in the BOEC $+\mathrm{Ab}$ group. In addition, the ratio of inner cell mass to total cell number was higher $(P<0.05)$ in the $B O E C$ group than in embryos incubated in the presence of $B O E C$ and anti-PDGF (19.6 versus $12.0 \%$ ). Two embryos in the PDGF group formed blastocysts, but only the total number of cells (69.2) could be determined owing to their poor morphology. An example of a bovine embryo cultured in the BOEC group stained with the double-dye technique is shown (Fig. 3).

\section{Discussion}

This study demonstrated that PDGF stimulated embryo development beyond the 8-cell stage. In addition, development to the morula stage was similar for embryos incubated with PDGF and with oviductal cells. However, those embryos incubated with oviductal cells developed further (blastocyst stage) during the culture period than did PDGF-treated embryos. This study is the first to demonstrate that removal of PDGF effects with antibodies inhibits embryonic development. After neutralization of PDGF-treated embryos with anibodies (PDGF $+\mathrm{Ab}$ ), embryonic development was similar to that of control embryos. The addition of anti-PDGF to oviductal cells (BOEC $+\mathrm{Ab}$ ) also resulted in a $40 \%$ reduction of blastocyst formation compared with BOEC-treated embryos. The continued development of some embryos $(17 \%)$ in the BOEC + Ab group may indicate that a short-term inhibition of PDGF action is overcome by continued secretion of PDGF by oviductal cells providing a developmental stimulus for further cell division. Alternatively, or additionally, the secretion of other growth factors by the oviductal epithelium may override the initial inhibitory effects imposed on embryo development by antiPDGF. However, the addition of anti-PDGF antibody to oviductal cells at a concentration of $1 \mathrm{mg} \mathrm{ml}^{-1}$ did not completely inhibit blastocyst formation (data not shown) suggesting the secretion of other stimulatory factors by oviductal cells.

Incubation of embryos with oviductal cells and anti-PDGF antibodies resulted in a reduced number of inner cell mass cells. In addition, the ratio of inner cell mass to total cells was lower in the $\mathrm{BOEC}+\mathrm{Ab}$ group than in embryos in the BOEC group. It is not clear whether inhibition of the PDGF effect with antibodies delays differentiation of embryonic blastomeres into 
Table 2. Relationship between the number of inner cell mass and trophectoderm cells following in vitro culture

\begin{tabular}{lcccc}
\hline $\begin{array}{l}\text { Culture } \\
\text { treatment }\end{array}$ & $n$ & $\begin{array}{c}\text { Total cell } \\
\text { number }\end{array}$ & $\begin{array}{c}\text { Inner cell } \\
\text { mass number }\end{array}$ & $\begin{array}{c}\text { Proportion } \\
(\%)\end{array}$ \\
\hline BOEC & 15 & $88.9 \pm 7.3^{\mathrm{a}}$ & $18.3 \pm 2.1^{\mathrm{a}}$ & $\begin{array}{c}19.6 \pm 1.2^{\mathrm{a}} \\
(11.8-26.5)\end{array}$ \\
$\mathrm{BOEC}+\mathrm{Ab}$ & $\begin{array}{c}(34-148) \\
\text { Range }\end{array}$ & $\begin{array}{c}79.4 \pm 8.1^{\mathrm{a}} \\
(46-120)\end{array}$ & $\begin{array}{c}9.8 \pm 2.4^{\mathrm{b}} \\
(2-19)\end{array}$ & $\begin{array}{c}12.0 \pm 1.3^{\mathrm{b}} \\
(4.4-21.4)\end{array}$ \\
\hline
\end{tabular}

Values are means $\pm \mathrm{SEM}$.

Values within columns with different superscripts are significantly different $(P<0.05)$.

BOEC: bovine oviductal epithelial cells; $B O E C+A b$; bovine oviductal epithelial cells plus platelet-derived growth factor antibody.

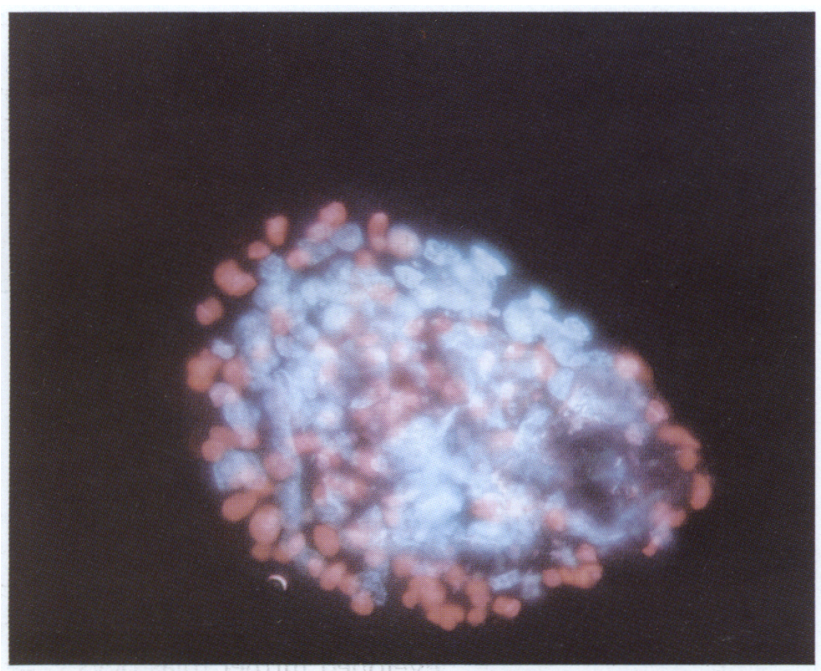

Fig. 3. A bovine embryo co-cultured with oviductal cells until 7 days following in vitro fertilization and differentially stained with propidium iodide and Hoechst stain to distinguish the inner cell mass. The inner cell mass was positioned dorsal to the trophectoderm prior to fixation on the slide $(\times 240)$.

inner cell mass cells or whether the rate of mitosis of inner cell mass cells is adversely affected. Another possibility is that anti-PDGF antibodies affect the integrity of the inner cell mass cells resulting in an indistinct inner cell mass, thereby allowing complement-mediated lysis during immunosurgery and staining with propidium iodide.

Larson et al. (1992) suggested that the ability of PDGF to signal activation of the embryonic genome is independent of TGF- $\beta$ and bFGF action, but TGF- $\alpha$ and bFGF may act synergistically to promote blastulation in PDGF-treated embryos. Results of our study also indicate that PDGF alone can stimulate embryonic development to the morula stage. Larson et al. (1992) also suggested that, following its acceleration of the fourth cell cycle, PDGF inhibits embryo blastulation. However, results from our study suggest that the apparent inhibition of blastocyst formation by PDGF is probably due to poor embryonic survival rates or suboptimal culture conditions, i.e. more PDGF-treated embryos degenerated during culture owing to the absence of additional development stimuli (possibly from TGF- $\alpha$, TGF- $\beta$ or bFGF) required at the fifth cell cycle.

Watson et al. (1992) demonstrated that PDGF-A, TGF- $\alpha$ and TGF- $\beta 2$ genes were expressed in bovine embryos as both maternal and embryonic transcripts. In addition, the PDGF- $\alpha$ receptor gene was a product of maternal and embryonic origin in bovine embryos. Munson et al. (1992) reported that TGF- $\beta$ and PDGF act synergistically to promote proliferation of bovine trophoblastic cells and endometrial cells during in vitro culture. A greater mitogenic response resulted from combining TGF- $\beta$ and PDGF-AB compared with TGF- $\beta$ and PDGF-BB. Marquant-Le Guienne et al. (1989) noted that TGF- $\beta$ stimulated mitotic activity of inner cell mass cells of bovine embryos that may have been mediated via its actions on the somatic cells during co-culture. Previously, Wood and Kaye (1989) failed to demonstrate a stimulatory effect of EGF on mouse embryo development. However, EGF stimulated uptake of $\left[{ }^{3} \mathrm{H}\right]$ leucine in late morulae and blastocyst stage embryos, and the increased protein synthesis was specific to trophectodermal cells. It was concluded that EGF stimulation was specific to trophectoderm cells and that EGF expression may occur at the late morula stage. These results are further supported by a report that specific binding of EGF is restricted to trophoblast outgrowths during in vitro culture (Adamson and Meek, 1984).

The reduction of inner cell mass cells and the proportion of inner cell mass to total cells following treatment with antiPDGF antibodies may be related to the cellular actions of PDGF. The actions of growth factors may include effects on their mitosis or differentiation and direct influences on the embryo or its uterine environment (Rappolee et al., 1988). PDGF may elicit the synthesis of specific proteins necessary for mitosis in the inner cell mass following differentiation. In cultured 3T3 cells, PDGF stimulates the synthesis of cyclin (Bravo and Macdonald-Bravo, 1984). In addition, the expression of c-myc or c-fos may have been limiting following treatment with anti-PDGF antibodies. Larson (1991) noted that the expression of c-myc and c-fos was detected in PDGFtreated embryos but not in developmentally arrested embryos. Similarities exist between the absence of c-myc and c-fos expression in cell lines arrested in the G0 state (Baserga, 1985; Pardee, 1989) and developmentally arrested bovine embryos (Larson, 1991). These proto-oncogenes, activated prior to the period of cell differentiation of trophectoderm and inner cell mass, may 
regulate formation of the inner cell mass. It is unclear whether PDGF initiates activation of the embryonic genome or drives embryo development after genome activation. However, it is plausible to assume that PDGF drives embryo development after activation, since the developmental 'block' in cultured bovine embryos is not due to failure of the embryonic genome to initiate transcription (Barnes and First, 1991).

This study strongly suggests that at least a part of the beneficial effect of co-culture of bovine embryos with oviductal epithelium is due to platelet-derived growth factor. The roles of other growth factors in regulating embryo differentiation have yet to be fully determined. However, the oviductal epithelium may serve as a source of these growth factors. Determining the mechanisms of growth factor regulation of inner cell mass formation may provide an efficient method for studying embryonic differentiation in vitro.

The authors are grateful to J. F. Dickey (Clemson University) and his staff for supplying the ovarian tissue, J. R. Giles (Cornell University) for the antibody used for immunosurgery and Y. Menezo (INSA) and API Biomerieux (France) for providing the MB2 medium. Appreciation is also extended to J. R. Broussard and L. Zhang for laboratory assistance. The authors thank Louisiana Animal Breeders Cooperative for providing the semen used in the study. This manuscript was approved for publication by the Director of the Louisiana Agricultural Experiment Station as manuscript number 92-11-6173.

\section{References}

Adamson ED and Meek J (1984) The ontogeny of epidermal growth factor receptors during mouse development Developmental Biology 90 430-434

Barnes FL and Eyestone WH (1990) Early cleavage and the maternal zygotic transition in bovine embryos Theriogenology 33 141-152

Barnes FL and First NL (1991) Embryonic transcription in in vitro cultured bovine embryos Molecular Reproduction and Development 29 117-123

Baserga R (1985) The Biology of Cell Reproduction. Harvard University Press, Cambridge, MA

Blakewood EG, Jaynes JM, Johnson WA and Godke RA (1989) Using the amniotic cavity of the developing chick embryo for the in vitro culture of early-stage mammalian embryos Poultry Science 68 1695-1702

Blakewood EG, Pool SH, Prichard JF and Godke RA (1990) Culturing twoto eight-cell caprine embryos using domestic chicken eggs Molecular Reproduction and Development $27288-294$

Brackett BG and Oliphant G (1975) Capacitation of rabbit spermatozoa in vitro Biology of Reproduction 12 260-274

Bravo R and Macdonald-Bravo H (1984) Induction of the nuclear protein 'cyclin' in quiescent mouse $3 \mathrm{~T} 3$ cells stimulated by serum and growth factors: correlation with DNA synthesis EMBO Journal 3 3177-3181

Camous S, Heyman Y, Meziou W and Menezo Y (1984) Cleavage beyond the block stage and survival after transfer of early bovine embryos cultured with trophoblastic vesicles Journal of Reproduction and Fertility 72 479-485

Ellington JE, Farrell PB, Simkin ME, Foote RH, Goldman EE and McGrath AB (1989) Development and survival after transfer of cow embryos cultured from 1-2 cells to morulae or blastocysts in rabbit oviducts or in a simple medium with bovine oviduct epithelial cells Journal of Reproduction and Fertility $89293-299$

Eyestone WH and First NL (1989) Co-culture of early cattle embryos to the blastocyst stage with oviductal tissue or in conditioned medium Joumal of Reproduction and Fertility $85715-720$

Eyestone WH, Jones JM and First NL (1991) Some factors affecting the efficacy of oviduct tissue-conditioned medium for the culture of early bovine embryos Joumal of Reproduction and Fertility 92 59-64

Fukuda Y, Ichikawa M, Maito K and Toyoda Y (1990) Birth of normal calves resulting from bovine oocytes matured, fertilized, and cultured with cumulus cells in vitro up to the blastocyst stage Biology of Reproduction 42 114-119

Gandolf F and Moor RM (1987) Stimulation of early embryonic development in the sheep by co-culture with oviductal epithelial cells Joumal of Reproduction and Fertility $8123-28$
Gandolfi F, Brevini TAL, Modina S and Lauria A (1991) Detection and characterization of a growth factor in bovine oviduct secretions Journal of Reproduction and Fertility Abstract Series 7, Abstract 6

Goodeaux LL, Thibodeaux JK, Voelkel SA, Anzalone CA, Roussel JD, Cohen JC and Menezo Y (1990) Collection, co-culture and transfer of rhesus preimplantation embryos Assisted Reproductive Technology/Andrology 1 370-379

Heyman Y, Menezo Y, Chesne P, Camous S and Garnier V (1987) In vitro cleavage of bovine and ovine early embryos: improved development using co-culture with trophoblastic vesicles Theriogenology $2759-68$

Iwasaki S, Yoshiba N, Ushijima H, Watanabe S \& Nakahara T (1990) Morphology and proportion of inner cell mass of bovine blastocysts fertilized in vitro and in vivo Joumal of Reproduction and Fertility $90279-284$

Keefer CL (1992) Development of in vitro produced bovine embryos cultured individually in a simple medium: effects of EGF and TGF $\beta 1$ Theriogenology 37 (Abstract) 236

Larson RC (1991) Growth Factor Regulation of Early Bovine Embryo Development. PhD Thesis, Cornell University, Ithaca, NY

Larson RC, Ignotz GG and Currie WB (1992) Platelet derived growth factor (PDGF) stimulates development of bovine embryos during the fourth cell cycle Development 115 821-826

McCaffery C, McEvoy TG, Diskin MG, Gwazdauskas FC, Kane MT and Sreenan JM (1991) Successful co-culture of 1-4 cell cattle ova to the morula or blastocyst stage Journal of Reproduction and Fertility 92 119-124

Marquant-Le Guienne B, Gérard M, Solari A and Thibault C (1989) In vitro culture of bovine egg fertilized either in vivo or in vitro Reproduction Nutrition Development 29 559-568

Menezo Y, Testart J and Perrone D (1984) Serum is not necessary for human in vitro fertilization, early embryo culture, and transfer Fertility and Sterility $\mathbf{4 2}$ 750-755

Munson L, Wilkinson JE and Bechtel M (1992) Transforming growth factor- $\beta$ (TGF- $\beta$ ) and platelet-derived growth factor (PDGF) are synergistic mitogens for bovine trophoblastic and endometrial epithelial cells Biology of Reproduction 4667 (Abstract)

Pardee AB (1989) $G_{1}$ events and regulation of cell proliferation Science 246 603-608

Pinyopummintr T and Bavister BD (1991) In vitro-matured/in vitro fertilized bovine oocytes can develop into morulae/blastocysts in chemically defined, protein-free culture media Biology of Reproduction 45 736-742

Pool SH, Rorie RW, Pendleton RJ, Menino AR and Godke RA (1988) Culture of early-stage bovine embryos inside day- 13 and day- 14 precultured trophoblastic vesicles Annals of the New York Academy of Sciences 541 407-418

Pursel VG, Wall RJ, Rexroad CE, Jr, Hammer RE and Brinster RL (1985) A rapid whole-mount staining procedure for nuclei of mammalian embryos Theriogenology 24 687-691

Rappolee DA, Brenner CA, Schultz R, Mark D and Werb Z (1988) Developmental expression of PDGF, TGF $\alpha$ and TGF $\beta$ genes in preimplantation mouse embryos Science 241 1823-1825

Rexroad CE (1989) Co-culture of domestic animal embryos Theriogenology 31 105-117

Rexroad CE and Powell AM (1988) Co-culture of ovine ova with oviductal tissue in medium 199 Journal of Animal Science 66 947-953

Steel RGD and Torrie JH (1980) Principles and Procedures of Statistics; A Biomedical Approach. McGraw-Hill, NY

Thibodeaux JK, Menezo Y, Roussel JD, Hansel W, Goodeaux LL, Thompson DL, Jr and Godke RA (1992) Coculture of in vitro fertilized bovine embryos with oviductal epithelial cells originating from different stages of the estrous cycle Joumal of Dairy Science 75 1448-1455

Voelkel SA, Amborski GF, Hill KG and Godke RA (1985) Use of uterinecell monolayer culture system for micromanipulated bovine embryos Theriogenology $24271-281$

Watson AJ, Hogan A, Hahnel A, Wiemer KE and Schultz GA (1992) Expression of growth factor ligand and receptor genes in the preimplantation bovine embryo Molecular Reproduction and Development 31 87-95

Wiemer KE, Casey PL and Godke RA (1988) Short term storage of equine embryos on a fetal bovine uterine monolayer followed by transfer to recipients Proceedings of 11th International Congress on Animal Reproduction and Artificial Insemination 2198

Wood SA and Kaye PL (1989) Effects of epidermal growth factor on preimplantation mouse embryos Journal of Reproduction and Fertility 85 575-582

Zhang L, Denniston RS and Godke RA (1992) A simple method for in vitro maturation, in vitro fertilization and co-culture of bovine oocytes Joumal of Tissue Culture Methods 14 107-112 